\title{
Why small towns can not share the benefits of urbanization in China?
}

DOI:

10.1016/j.jclepro.2017.10.150

\section{Document Version}

Accepted author manuscript

Link to publication record in Manchester Research Explorer

\section{Citation for published version (APA):}

Shen, L., Ren, Y., Xiong, N., Li, H., \& Chen, Y. (2018). Why small towns can not share the benefits of urbanization in China? Journal of Cleaner Production, 174, 728. https://doi.org/10.1016/j.jclepro.2017.10.150

\section{Published in:}

Journal of Cleaner Production

\section{Citing this paper}

Please note that where the full-text provided on Manchester Research Explorer is the Author Accepted Manuscript or Proof version this may differ from the final Published version. If citing, it is advised that you check and use the publisher's definitive version.

\section{General rights}

Copyright and moral rights for the publications made accessible in the Research Explorer are retained by the authors and/or other copyright owners and it is a condition of accessing publications that users recognise and abide by the legal requirements associated with these rights.

\section{Takedown policy}

If you believe that this document breaches copyright please refer to the University of Manchester's Takedown Procedures [http://man.ac.uk/04Y6Bo] or contact uml.scholarlycommunications@manchester.ac.uk providing relevant details, so we can investigate your claim.

\section{OPEN ACCESS}


Shen, L., Ren, Y., Xiong, N., Li, H., \& Chen, Y. (2018). Why small towns can not share the benefits of urbanization in China?. Journal of cleaner production, 174, 728-738.

https://doi.org/10.1016/i.jclepro.2017.10.150

\title{
Why small towns can not share the benefits of urbanization in China?
}

\author{
Liyin Shen ${ }^{\text {a, b}}$, Yitian Ren ${ }^{\text {a, b }}$, Ning Xiong a, b, Heng Li ${ }^{\text {c }}$, Yang Chen a, b \\ a School of Construction Management and Real Estate, Chongqing University, Chongqing, PR China \\ b International Research Center for Sustainable Built Environment, Chongqing University, Chongqing, PR \\ China \\ c Department of Building and Real Estate, The Hong Kong Polytechnic University, Kowloon, Hong Kong \\ *Corresponding author.
}

\begin{abstract}
The urbanization process over last several decades in China has brought benefits in multiple dimensions throughout the country. However, it appears that the benefits shared by small towns is very limited, and this is particular the case in Southwest China. This paper examines holistically the barriers against benefit-sharing by small towns in the urbanization process in China. Theory of Constraints (TOC) has been applied in this study in producing a holistic barrier-framework for studying the significance and performance of individual barriers. 21 case townships are selected in Southwest China for field surveys, including interview discussions, on-site visits and data collections. The content analysis and Likert scale scoring approach are used to convert the survey data to score values. Those significant barriers are discussed in depth by examining practical cases extracted from the field surveys. The study presents the most significant barriers which limit the benefit-sharing by small towns in Southwest China, such as lack of talents, limited financing channels, loss of labor-force population, lack of infrastructure construction, mono-industry structure, low level management ability, and restricted jurisdiction power. The findings from this study provide valuable references to search for effective approaches for
\end{abstract}


promoting the development of small towns and contributing to the healthy and sustainable urbanization process in China.

Key Word: Urbanization, Urbanization benefits, Small towns, Barriers analysis, Case study, Southwest China

\section{Introduction}

China's rapid urbanization has been attracting the attention internationally in recent years (Yang, 2013). Since the introduction of reform programs in the year 1978 in China, millions of rural residents have migrated to cities and towns (Shen, 2006; Hubacek et al., 2009; Wang et al., 2015; Bao and Peng, 2016; Shen et al. 2017; Shuai et al. 2017). In 2015, China's urbanization has reached to the level of $56.1 \%$ with the urban population of 771.16 million (NBSC, 2016). The rapid urbanization process contributes to dramatic improvement of the economic performance in China, evidenced by the fact that the gross domestic product (GDP) has increased from US\$ 734.55 billion in 1995 to US\$ 11.07 trillion in 2015 (World Bank, 1996, 2016). According to the GDP scale, China has become the second largest country in 2015 (International Monetary Fund, 2016).

In addition to great economic contribution, the urbanization process in China has also brought a lot of social benefits (Shen et al. 2012). For example, the transportation system in China has been driven by urbanization and becomes well advanced, with the dramatic development of railway transit, expressway and highway. The advanced transportation system further enables the efficient flow for both population and resources throughout the country. The medical and healthcare services have been improved largely in line with the development of urbanization, with almost all people receiving effective medical treatment and healthcare insurance. The education system has also been improved accordingly, with young people having more chances to access to tertiary education. In fact, the number of 
enrollment in colleges and universities has increased substantially in line with urbanization development. According to official statistics, the university enrolment rate in China was $7 \%$ in the year 1978, with 400 thousand students being recruited to university students. But the enrollment rate increased to $74 \%$ in 2014 , with over 7 million students were admitted to the universities (NBSC, 2015). Graduates are also provided with more job opportunities in the more urbanized China. (Shen et al., 2016; Tan et al., 2017; Shuai et al., 2017).

Whilst the economic performance and social benefits have been promoted dramatically in the past several decades in line with urbanization in China, the difference in development between urban and rural areas remains significant (Peng et al., 2014; Peng, 2015). Lipton (1993) opined that resources are largely gathered and invested to cities in the urbanization process, which is called urban bias, and this is also the case in China. For example, according to the statistics, the average per capital net income of urban residents is almost three times as that of the rural residents in China in 2015 (NBSC, 2016). With this background, the Chinese government considers that the development of small towns is a strategic approach to narrow the disparity between urban and rural areas (The Government Work Report by Premier Li Keqiang, 2015). For implementing this strategy, small towns are given more attention, which is addressed in the official document "The National New-type Urbanization Plan (2014-2020)" (China State Council, 2014). Various studies have also appreciated the crucial role of small towns in China in receiving surplus rural population (Wang et al., 2015; Chen et al., 2015). As the connectors and transfer stations between cities and countryside, small towns are expected to contribute to narrowing the gap between urban and rural area and achieving the mission of new-type urbanization in China.

Nevertheless, small towns in China are still severely underdeveloped in comparing to large cities. It appears that small towns have shared very limited benefits brought by urbanization process (Shi, 2013; Gu et al., 2015), and this is 
particularly the case in Southwest China. Guo et al. (2014) evaluated the development level of small towns in different regions in China and found that the small towns in East China is much more advanced than that in the rest of China. In fact, the small towns in Southwest China severely lag behind those in other regions in China, and they are weak in infrastructure construction, investment attraction, industry foundation and population aggregation. According to statistics, the number of small towns in Southwest China accounts for $21 \%$ of the total number of small towns in China (NBSC, 2014). It indicates that the failure in sharing the urbanization benefits by these small towns can impede significantly the further development of urbanization in China.

The barriers hindering small towns from sharing urbanization benefits in China are in multiple dimensions, such as lack of finance for infrastructure development and shortage of talents. Without addressing these barriers, the small towns will not be able to make significant development and the Chinese overall urbanization mission will be jeopardized. Therefore, it is essential to understand these barriers, thus effective actions can be taken to address them, and accordingly these small towns can receive proper help to develop.

Previous studies have investigated various types of barriers affecting the development of small towns in China. For example, Chen and Liu (2004) examined the institutional barriers having influences on the development of small towns in China, including the lack of authority for protecting local resources and producing township plans. Liu et al. (2006) studied the phenomenon of idle land in small towns in Guangdong Province, and pointed out that the phenomenon is largely caused by the conflict between land supply and demand. Tian and Chang (2003) analyzed the main reasons for the underdevelopment of small towns from the economic perspective, focusing on the financial difficulty for infrastructure development. By comparing the small town development between China and Britain, Yu (2013) pointed out that many small towns in China are lack of basic infrastructures, which 
affects the township functions and contributes to the difficulty of absorbing surplus agricultural population from the circumjacent villages. In investigating the phenomenon of net out-migration in small towns, Zhang (2012) pointed out that the population in some small towns cannot perceive a good development future, thus they migrate to other cities. The main barriers to the development of these net out-migration towns include the fund shortage for township infrastructure, lack of industry for driving the economic development, shortage of educated people and the weak governance capacity. Fang et al. (2014) conducted a study about the township development in Southwest region of China and pointed out that ecologic constraints are the major barriers to the development of the small towns in this region.

There are other existing studies concerning the issues of small town development in China. Particularly, the development model of small towns in East China has been well examined. Luo et al. $(2000,2011)$ found that the development of small towns in Jiangsu Province is dominated by developing Township and Village Enterprises (TVEs). The studies by Song (2004) and Lu and Huang (2012) show that the development of small towns in Pearl River Delta (PRD) is driven by export-oriented economic activities, as they have both the advantage of favorable policies granted by central government and the geographic superiority of neighboring with the advanced economic region of Hong Kong. Qi et al. (2012) and Cui and Zhao (2013) considered that the development of the towns located in coastal areas of Southeast China presents a model of in-situ urbanization.

Nevertheless, the above discussions demonstrate that the previous research works have not provided a holistic picture on the barriers affecting the development of small towns in the process of urbanization in China. In particular, little research work was conducted in examining the development of small towns in those underdevelopment regions, such as Southwest China. It is therefore the aim of this study to analyze the barriers that prevent small towns from sharing the benefits of urbanization in the context of Southwest China. The rest of this paper will be 
organized as follows. Section 2 describes the research methods. In section 3, based on the Theory of Constraints (TOC), a holistic framework is proposed for examining the barriers to the development of small towns. Section 4 presents the research data and analysis on barrier significance. Section 5 presents discussions on the implications of barriers to small town development, followed by the conclusion in the last section.

\section{Research method}

This research adopts case study method to examine and analyze the barriers to the development of small towns in the context of Southwest China. The research roadmap is planned, as shown in Figure 1. Case study method is appreciated as an effective methodology in conducting social observation through practical surveys and investigations, with the aim of reflecting the essence of the investigated objectives (Stake, 1983).

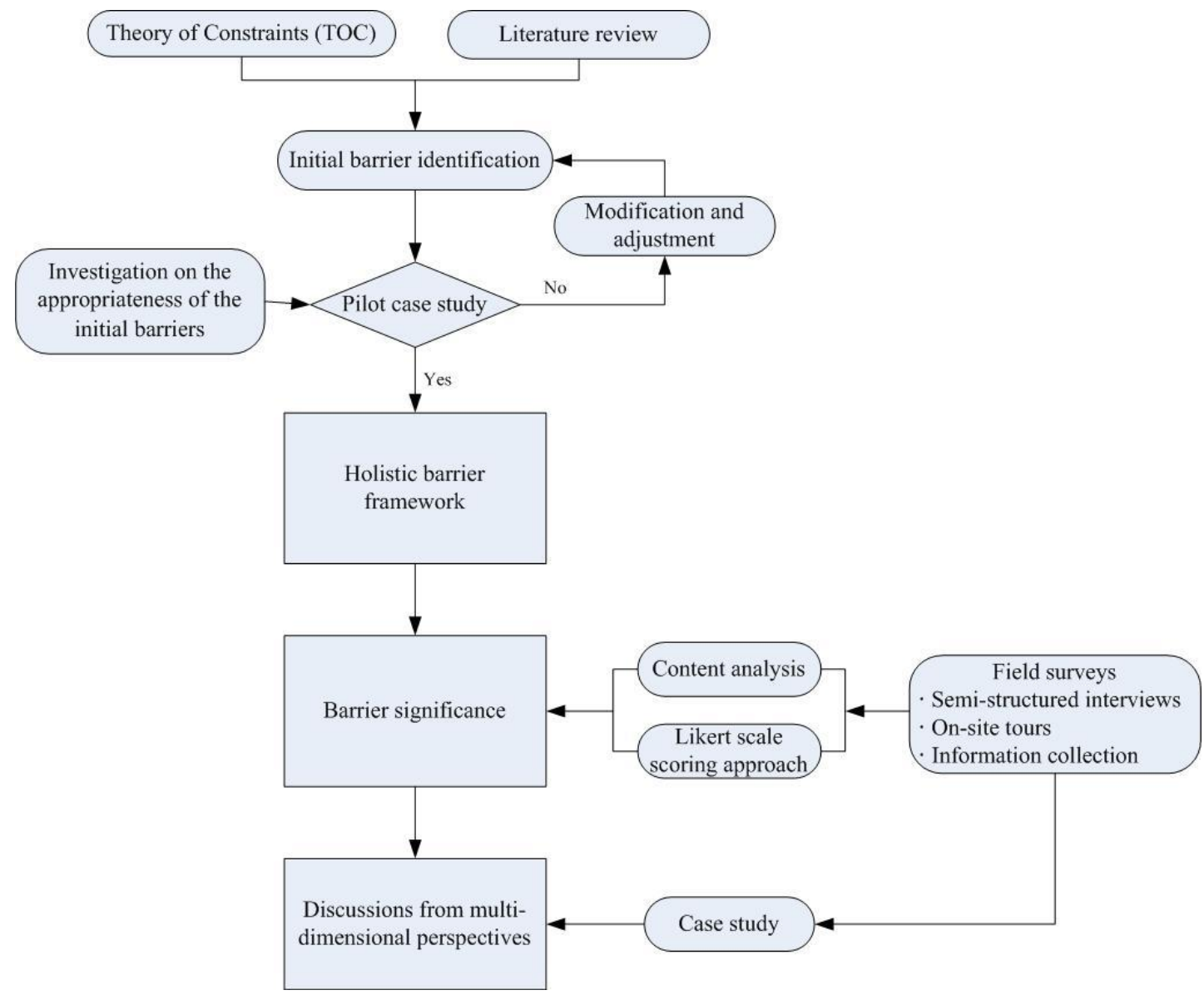

Figure 1 Research roadmap 
As planned in Figure 1, firstly, the appreciation of the Theory of Constraints (TOC) and literature review are conducted to gain theoretical understanding on the barriers to the development of small towns in China. Following the literature studies, initial barrier identifications are produced, which will be tested by two pilot studies. The purpose of the two pilot studies is to investigate the appropriateness of the initial barriers in reflecting the circumstance of small towns in the context of Southwest China, and modifications will be made to the barrier framework where necessary. As a result, a holistic barrier framework is formulated.

By using the holistic barrier framework, field surveys are conducted to 21 case towns to collect data about the performance and significance of individual barriers to specific townships. Field survey is the crucial part of this research. It not only helps collect data for analysis, but also supports the discussions. In the survey process for each case town, semi-structured interviews were conducted with the officials of the township government, who are in charge of key township sectors including economy department, infrastructure construction, urban development, public security, education, and environment protection. The contents of semi-structured interviews were designated to cover the following aspects: current development status, self-borne resources for development, future development plan, typical barriers to the township development, and solutions to the township development. In addition to interviews, on-site tours were also conducted in each case township to gain further observations on the practice of township development. Therefore, the data collected from field surveys are in the form of interview results, on-site observations, various types of official documents, and the statistical yearbooks of the concerned towns.

Following the data collection from field surveys to 21 case towns, content analysis and Likert scale scoring approach are used to convert the surveyed data and content responses from practitioners to score values. And these score values are used to present the significance level of individual barriers. Content analysis involves 
combing and mining the documents and files, which is widely used in social science research (Weber, 1990; Yu et al., 2015). Likert scale scoring method is a proven effective approach to scale responses in conducting survey research (Rasmussen, 1989; Rogers et al., 2001; Langmack et al., 2015; Peng et al., 2015). Following the above research procedures, discussions are conducted on the implications of those significant barriers.

\section{Holistic barrier framework}

The Theory of Constraints (TOC), developed by Goldratt in 1980s (Goldratt, 2005), is a typical principle for supporting studies on examining constraints or barriers in the research fields of enterprises management, healthcare, project management, supply chain management, etc. (Balderstone and Mabin, 1998, 2013; Cohen et al., 2004; Watson et al., 2007; Golmohammadi, 2015; Puche et al., 2016). The application of TOC aims to eliminate the restrictions or bottlenecks of a management system, and improve the performance of the system. Aguilar-Escobar et al. (2016) applied TOC in examining the barriers of providing logistics service in a hospital and identified eight groups of barriers across physical, political, economic and other dimensions. By applying TOC, Costas et al. (2015) identified the bottlenecks in a multi-agent supply chain system for helping formulate effective measures to reduce the Bullwhip Effect in the system.

The emphasis in applying the principle of TOC is the holistic view of investigating constraints or barriers. According to this principle, this study integrates the results of barrier identifications presented in previous studies and produces a holistic barrier framework. The typical barriers to township development in the context of Southwest China have been discussed by various researchers, listed in Table 1. However, it can be seen that any of these individual studies in Table 1 does not present a holistic view. By integrating the existing works in Table 1, a holistic picture of an initial list of barriers can be produced, as shown in Table 2. 
Table 1 Typical township development barriers presented in literatures

\begin{tabular}{|c|c|c|c|}
\hline Researcher & Barriers identified in previous study & Researcher & Barriers identified in previous study \\
\hline $\begin{array}{c}\text { Zhen } \\
\text { and Zhao } \\
\text { (2016) }\end{array}$ & $\begin{array}{l}\text { - Lack of financial support for infrastructure construction } \\
\text { - Low level management capacity in township government } \\
\text { - Mono-industry structure } \\
\text { - Lack of long-term plan for township development }\end{array}$ & $\begin{array}{c}\text { Wang and Sun } \\
\text { (2016) }\end{array}$ & $\begin{array}{l}\text { - Mono-industry structure } \\
\text { - Lack of financial support for infrastructure construction } \\
\text { - Low level management capacity in township government } \\
\text { - Difficulty for forming scale economy due to the diffused } \\
\text { distribution of township enterprises }\end{array}$ \\
\hline $\begin{array}{c}\text { Fang et al. } \\
\text { (2014) }\end{array}$ & $\begin{array}{l}\text { - The topographic variety and complexity } \\
\text { - Frequent natural disaster } \\
\text { - Difficulty of industry transformation induced by the } \\
\text { implementation of environmental protection policy } \\
\text { - Limited ecological carrying capacity }\end{array}$ & $\begin{array}{c}\text { Yu and Peng } \\
\text { (2014) }\end{array}$ & $\begin{array}{l}\text { - Difficulty of forming scale economy due to the diffused } \\
\text { distribution of township enterprises } \\
\text { - Mono-industry structure } \\
\text { - Low level of land utilization because of topographic complexity } \\
\text { - Limited channels for obtaining financial resources }\end{array}$ \\
\hline $\begin{array}{l}\text { Zhang } \\
\text { (2011) }\end{array}$ & $\begin{array}{l}\text { - Unsuitable industry structure adopted } \\
\text { - Mono-industry structure } \\
\text { - Lack of policy support to the development of township and } \\
\text { village enterprises } \\
\text { - Limited channels for obtaining financial resources } \\
\text { - Lack of local peasants' participation in decision-making process } \\
\text { for township development }\end{array}$ & $\begin{array}{l}\text { Wang } \\
(2011)\end{array}$ & $\begin{array}{l}\text { - Unsuitable industry structure adopted } \\
\text { - Self-borne feebleness on developing economic activities } \\
\text { - The employment pressure from peasants who have lost their } \\
\text { lands in urbanization process } \\
\text { - Weak public service } \\
\text { - Insufficient security systems }\end{array}$ \\
\hline $\begin{array}{l}\text { Wu and Liu } \\
\text { (2012) }\end{array}$ & $\begin{array}{l}\text { - Weak administration power for township government } \\
\text { - Limited channels for obtaining financial resources } \\
\text { - Lack of policy support to the development of township and } \\
\text { village enterprises } \\
\text { - Restrictions on township development by land use policy }\end{array}$ & $\begin{array}{c}\text { Chen and Liu } \\
\text { (2004) }\end{array}$ & $\begin{array}{l}\text { - Less resources invested to the bottom layer (small towns) in the } \\
\text { hierarchical administrative management system } \\
\text { - Low level management capacity in township government } \\
\text { - Lack of construction land use quotas for township development } \\
\text { - Lack of financial support for infrastructure construction }\end{array}$ \\
\hline
\end{tabular}


- Less resources invested to the bottom layer (small towns) in the hierarchical administrative management system

- The small towns' weaker position in attracting development resources due to the increasing gap between urban-rural areas in the urbanization process

- Population migration to cities in urbanization process

- The employment pressure from peasants who have lost their lands in urbanization process

- Weak public service

- Insufficient security systems
- Less resources invested to the bottom layer (small towns) in the hierarchical administrative management system

- Unsuitable industry structure adopted

- Lack of financial support for infrastructure construction

- Self-borne feebleness on developing economic activities

- Less developed transportation system because of the

topographic complexity

- Lack of construction land use quotas for township development 
Table 2 Initial barrier identifications

- Difficulty of forming scale economy due to the spatially diffused distribution of township enterprises

- Difficulty of industry transformation induced by the implementation of environmental protection policy

- Employment pressure from peasants who have lost their lands in urbanization process

- Frequent natural disaster

- Lack of construction land use quotas for township development

- Lack of financial support for infrastructure development

- Lack of long-term plan for township development

- Lack of policy support to the development of township enterprises

- Less resources invested to the township layer in the hierarchical administrative management system
Limited ecological carrying capacity

- Low level of land utilization because of topographic complexity

- Low level management capacity in township government

- Mono-industry structure

- Population migration to cities in urbanization process

- Restrictions to township development by land use policy

- Self-borne feebleness for developing economic activities

- Small towns' weaker position in attracting development resources due to the increasing gap between urban-rural areas in the urbanization process

- Topographic variety and complexity

- Unsuitable industry structure adopted

- Weak administration power for township government

- Weak public service and insufficient security systems

- Limited channels for obtaining financial resources 
The research team presented the initial barrier identifications to practitioners in two pilot studies for testing the appropriateness of the barriers in the context of Southwest China. One pilot study involves two practitioners with the other pilot study involving three. By incorporating the practitioners' comments and suggestions, modifications and adjustment are made to the initial barrier identifications. As a result, the holistic barrier framework is produced, as shown in Figure 2, which is composed of four dimensions of barriers, namely institutional, economic, social and ecologic barriers.

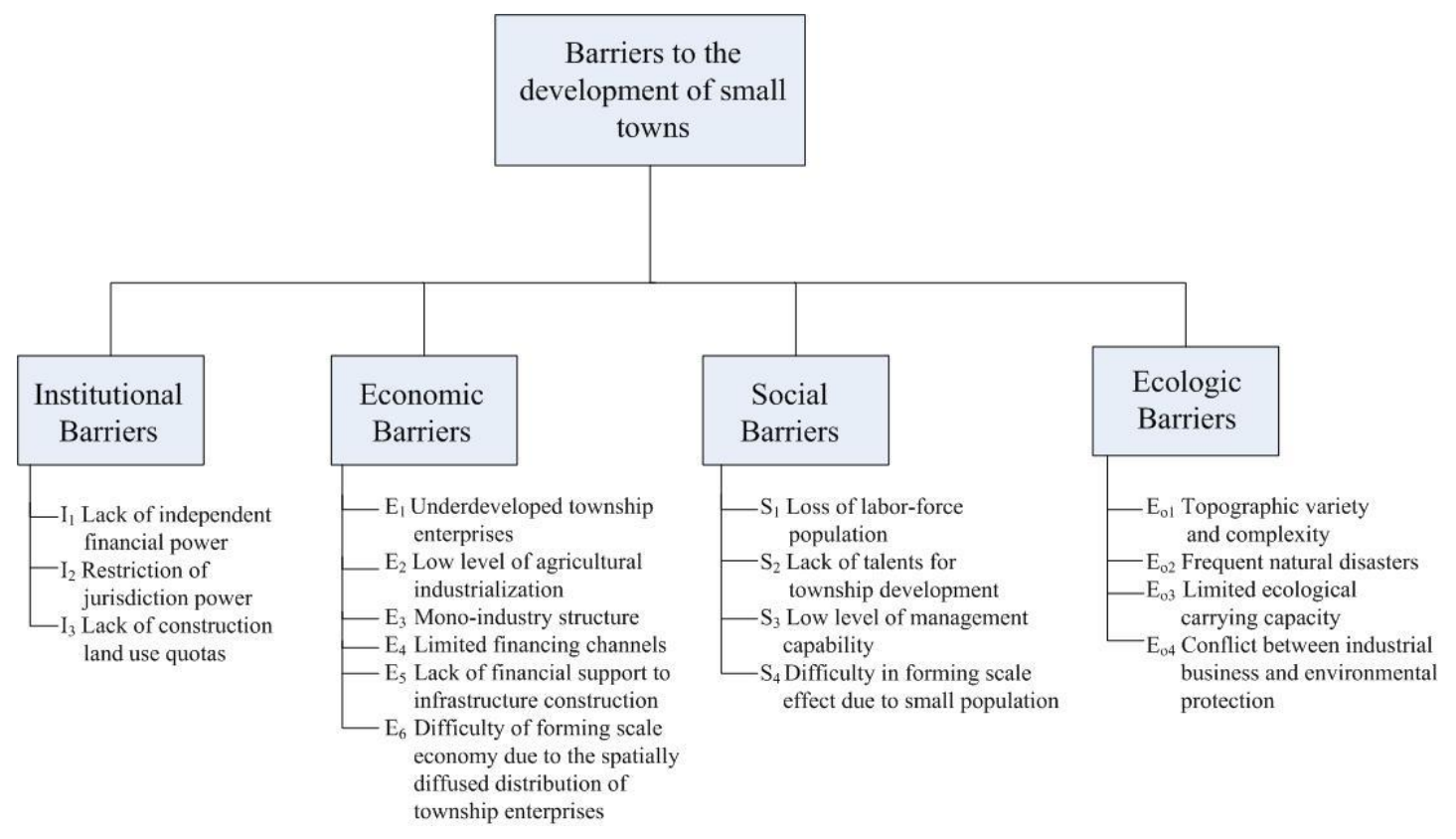

Figure 2 Holistic barrier framework

\section{Research data and analysis}

In referring to the holistic barrier framework in Figure 2, field surveys were conducted to 21 towns in order to collect data for analysis. The 21 case towns include seven in Chongqing Municipality City, four in Sichuan Province, six in Guizhou Province and four in Hubei Province. Although the four towns in Hubei Province are not belong to Southwest region by administration definition, they are geographically adjacent to Chongqing Municipality City and are typical mountainous towns. And the senior officials in these four towns are very supportive to this research by providing the access for field surveys and in-depth interview 
discussions, thus they are also considered representative as case towns for the study.

The 21 towns are considered having representative characteristics of townships in Southwest China. The spatial distribution of the 21 surveyed towns is shown in Figure 3. The field surveys were conducted during the period of March to October 2016, with the details in Table 3.

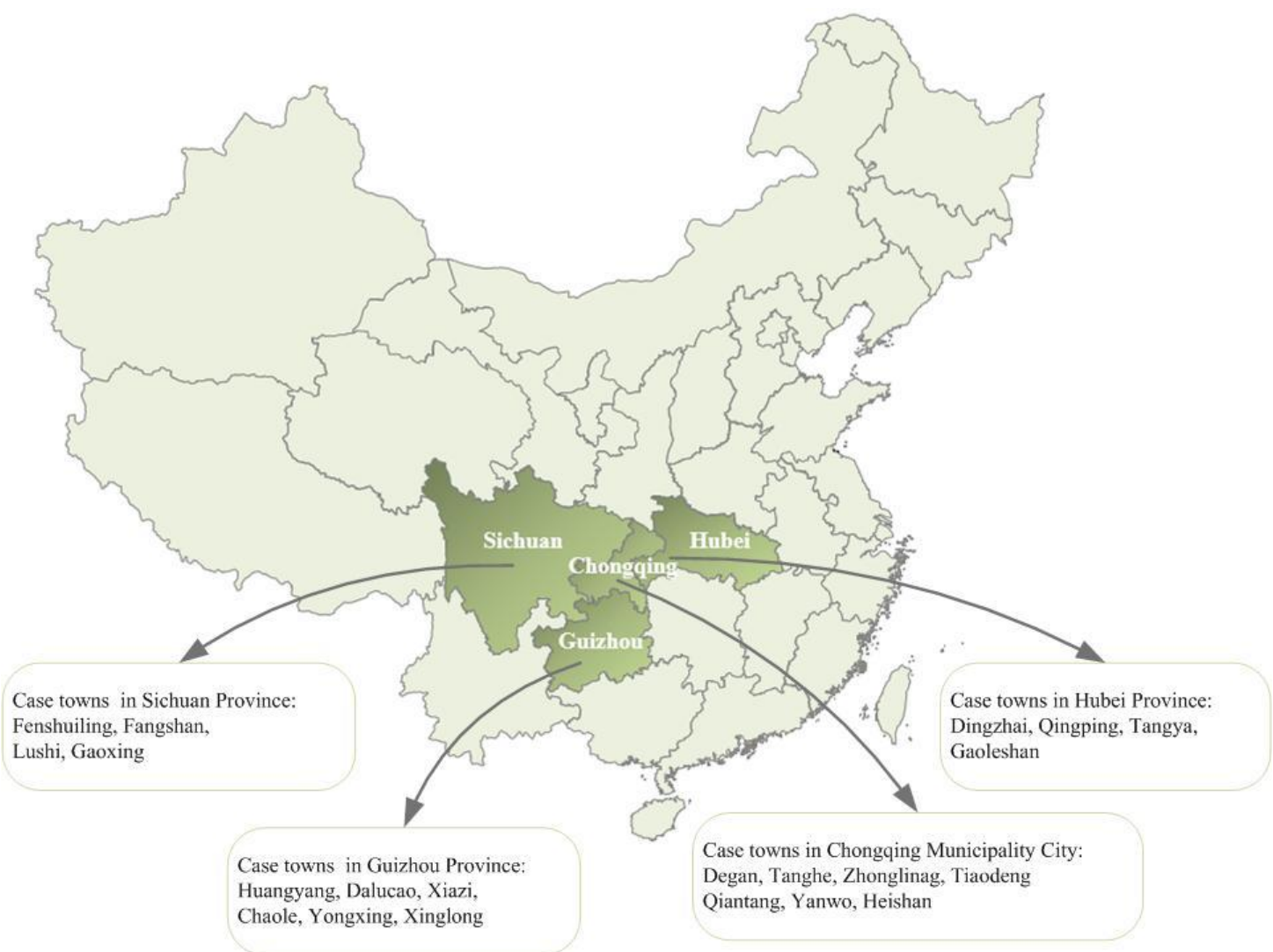

Figure 3 Spatial distribution of the 21 case townships

Table 3 The survey schedules in 21 case townships in Southwest China

\begin{tabular}{lcc}
\hline Survey time & Case towns & Location \\
\hline March, 2016 & Degan & Chongqing Municipality \\
March, 2016 & Tanghe & Chongqing Municipality \\
April, 2016 & Fenshuiling & Luzhou, Sichuan Province \\
April, 2016 & Fangshan & Luzhou, Sichuan Province \\
June, 2016 & Zhongliang & Chongqing Municipality \\
June, 2016 & Tiaodeng & Chongqing Municipality \\
July, 2016 & Lushi & Guangan, Sichuan Province \\
July, 2016 & Gaoxing & Guangan, Sichuan Province
\end{tabular}




\begin{tabular}{lcc} 
August, 2016 & Huangyang & Zunyi, Guizhou Province \\
August, 2016 & Dalucao & Zunyi, Guizhou Province \\
August, 2016 & Xiazi & Zunyi, Guizhou Province \\
August, 2016 & Chaole & Zunyi, Guizhou Province \\
August, 2016 & Yongxing & Zunyi, Guizhou Province \\
August, 2016 & Xinglong & Zunyi, Guizhou Province \\
September, 2016 & Dingzhai & Enshi Prefecture, Hubei Province \\
September, 2016 & Qingping & Enshi Prefecture, Hubei Province \\
September, 2016 & Tangya & Enshi Prefecture, Hubei Province \\
September, 2016 & Gaoleshan & Enshi Prefecture, Hubei Province \\
September, 2016 & Qiantang & Chongqing Municipality City \\
September, 2016 & Yanwo & Chongqing Municipality City \\
October, 2016 & Heishan & Chongqing Municipality City \\
\hline
\end{tabular}

In the survey process, interview discussions were conducted in all 21 case towns. The interviewees were invited firstly to respond the open-ended question "how significant is this barrier in your township?", and informed that their responses would be converted into score values for facilitating analysis by using Likert scale scoring method. According to the interviewees' responses, which are descriptive and in details, the research team propose a significance score between 1 and 5, and invite the interviewees' further views on the appropriateness of the score. A score of "5" refers that the concerned barrier has most significant influence on the development of case townships, " 4 " refers a significant influence, "3" refers a common barrier, " 2 " indicates that the barrier has no significant influence, and " 1 " refers a negligible barrier. By this approach, the significance of each barrier to each case township is quantified, with a specific score agreed between the interviewees attended. The results of the interview discussions are shown in Table 4, indicating the degree of significance of each barrier in referring to a specific case town, and the parameter $\mu$ refers the mean significance value of each barrier between the 21 case towns. 
Table 4 Data from surveys on the barrier significance

\begin{tabular}{|c|c|c|c|c|c|c|c|c|c|c|c|c|c|c|c|c|c|}
\hline \multirow[t]{2}{*}{ Case Town } & \multicolumn{3}{|c|}{ Institutional Barriers } & \multicolumn{6}{|c|}{ Economic Barrier } & \multicolumn{4}{|c|}{ Social Barrier } & \multicolumn{4}{|c|}{ Ecologic Barrier } \\
\hline & $\mathrm{I}_{1}$ & $\mathrm{I}_{2}$ & $\mathrm{I}_{3}$ & $\mathrm{E}_{1}$ & $\mathrm{E}_{2}$ & $\mathrm{E}_{3}$ & $\mathrm{E}_{4}$ & $\mathrm{E}_{5}$ & $\mathrm{E}_{6}$ & $\mathrm{~S}_{1}$ & $\mathrm{~S}_{2}$ & $\mathrm{~S}_{3}$ & $\mathrm{~S}_{4}$ & $\mathrm{E}_{\mathrm{o} 1}$ & $\mathrm{E}_{02}$ & $\mathrm{E}_{03}$ & $\mathrm{E}_{\mathrm{o} 4}$ \\
\hline Degan & 1 & 1 & 1 & 1 & 1 & 1 & 1 & 1 & 1 & 1 & 4 & 1 & 1 & 1 & 1 & 1 & 1 \\
\hline Tanghe & 5 & 3 & 3 & 4 & 5 & 5 & 5 & 5 & 4 & 5 & 5 & 5 & 2 & 3 & 1 & 3 & 1 \\
\hline Fenshuiling & 5 & 4 & 2 & 4 & 5 & 5 & 5 & 5 & 4 & 5 & 5 & 3 & 3 & 4 & 3 & 4 & 5 \\
\hline Fangshan & 5 & 5 & 3 & 3 & 4 & 5 & 5 & 5 & 3 & 5 & 5 & 3 & 4 & 3 & 1 & 3 & 4 \\
\hline Zhongliang & 5 & 5 & 5 & 5 & 4 & 5 & 5 & 5 & 5 & 4 & 4 & 3 & 4 & 5 & 1 & 4 & 5 \\
\hline Tiaodeng & 5 & 5 & 3 & 5 & 3 & 4 & 5 & 5 & 4 & 5 & 4 & 3 & 2 & 2 & 1 & 4 & 5 \\
\hline Lushi & 4 & 5 & 5 & 2 & 4 & 4 & 5 & 5 & 2 & 5 & 5 & 4 & 2 & 5 & 1 & 3 & 3 \\
\hline Gaoxing & 2 & 2 & 1 & 3 & 2 & 4 & 4 & 5 & 3 & 3 & 5 & 5 & 2 & 1 & 1 & 1 & 1 \\
\hline Huangyang & 3 & 5 & 1 & 1 & 5 & 5 & 4 & 5 & 2 & 5 & 5 & 4 & 2 & 1 & 1 & 1 & 4 \\
\hline Dalucao & 3 & 2 & 2 & 2 & 4 & 5 & 4 & 3 & 2 & 5 & 5 & 5 & 4 & 2 & 1 & 4 & 5 \\
\hline Xiazi & 3 & 2 & 2 & 2 & 2 & 5 & 4 & 4 & 2 & 5 & 5 & 4 & 1 & 1 & 1 & 2 & 2 \\
\hline Chaole & 4 & 5 & 5 & 2 & 3 & 5 & 5 & 4 & 2 & 5 & 4 & 5 & 2 & 1 & 1 & 3 & 3 \\
\hline Yongxing & 5 & 5 & 3 & 2 & 2 & 3 & 5 & 4 & 2 & 3 & 3 & 5 & 2 & 3 & 1 & 2 & 3 \\
\hline Xinglong & 3 & 2 & 2 & 3 & 4 & 3 & 5 & 3 & 3 & 3 & 5 & 3 & 2 & 2 & 1 & 3 & 3 \\
\hline Dingzhai & 3 & 4 & 3 & 2 & 2 & 3 & 3 & 3 & 2 & 3 & 4 & 5 & 2 & 1 & 1 & 4 & 4 \\
\hline Qingping & 4 & 5 & 1 & 2 & 3 & 2 & 5 & 5 & 2 & 5 & 5 & 4 & 2 & 3 & 1 & 2 & 2 \\
\hline Tangya & 4 & 5 & 3 & 3 & 3 & 4 & 5 & 5 & 3 & 5 & 5 & 4 & 2 & 2 & 1 & 1 & 1 \\
\hline Gaoleshan & 3 & 5 & 4 & 2 & 3 & 4 & 5 & 4 & 2 & 4 & 4 & 4 & 2 & 2 & 1 & 3 & 3 \\
\hline Qiantang & 3 & 2 & 2 & 2 & 2 & 3 & 5 & 3 & 2 & 4 & 3 & 3 & 2 & 5 & 1 & 2 & 2 \\
\hline Yanwo & 4 & 4 & 5 & 2 & 4 & 5 & 5 & 5 & 3 & 5 & 5 & 4 & 3 & 2 & 1 & 2 & 2 \\
\hline Heishan & 2 & 2 & 1 & 2 & 3 & 2 & 2 & 2 & 2 & 2 & 5 & 4 & 1 & 1 & 1 & 4 & 4 \\
\hline$\mu$ & 3.62 & 3.71 & 2.71 & 2.57 & 3.24 & 3.90 & 4.38 & 4.10 & 2.62 & 4.14 & 4.52 & 3.86 & 2.24 & 2.38 & 1.10 & 2.67 & 3.00 \\
\hline
\end{tabular}


The data in Table 4 can be further presented graphically in Figure 4 to Figure 8. Figure 4 demonstrates the mean value of significance of each barrier between case towns. Figure 5 to Figure 8 indicates the significance of individual barriers to each sample town from the perspectives of four dimensions respectively, namely, institutional, economic, social, and ecologic dimensions.

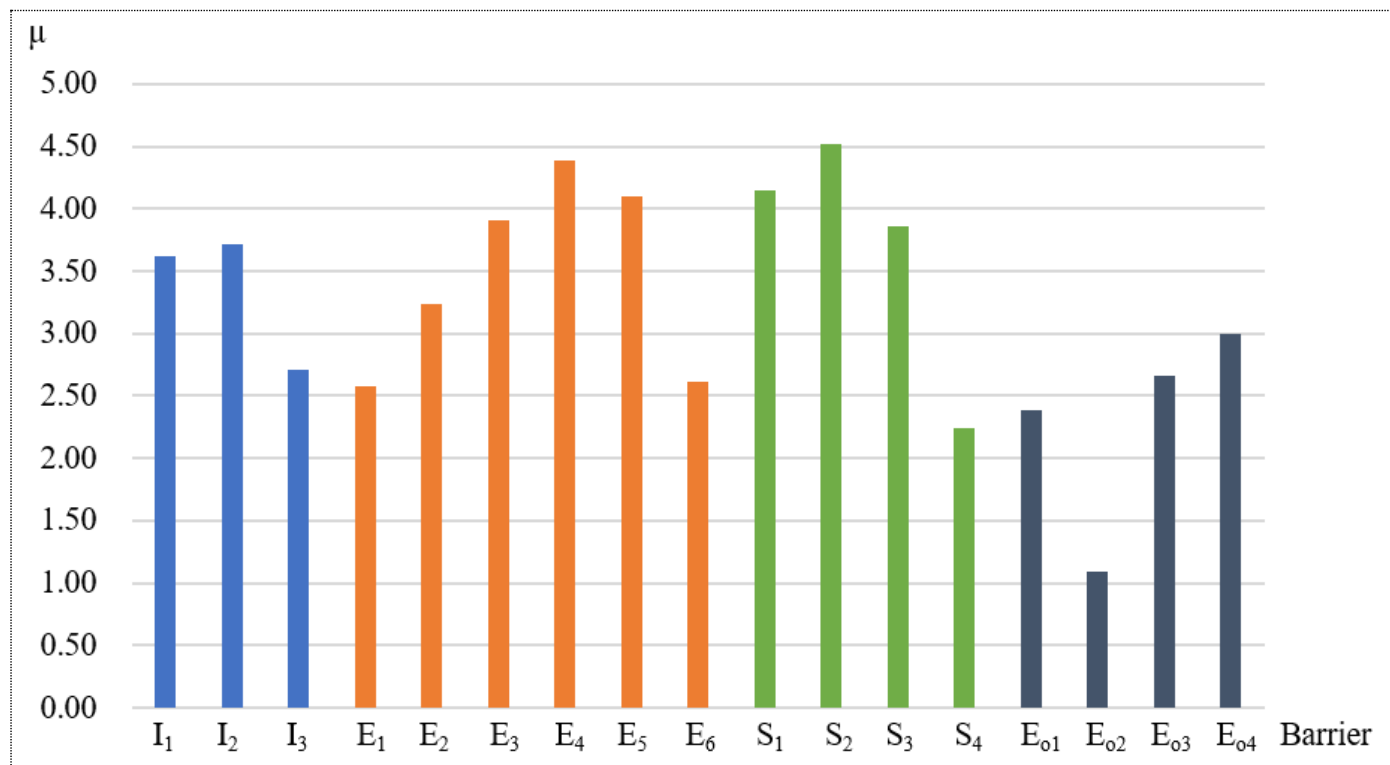

Figure 4 Mean significance value of each barrier across 21 sample towns

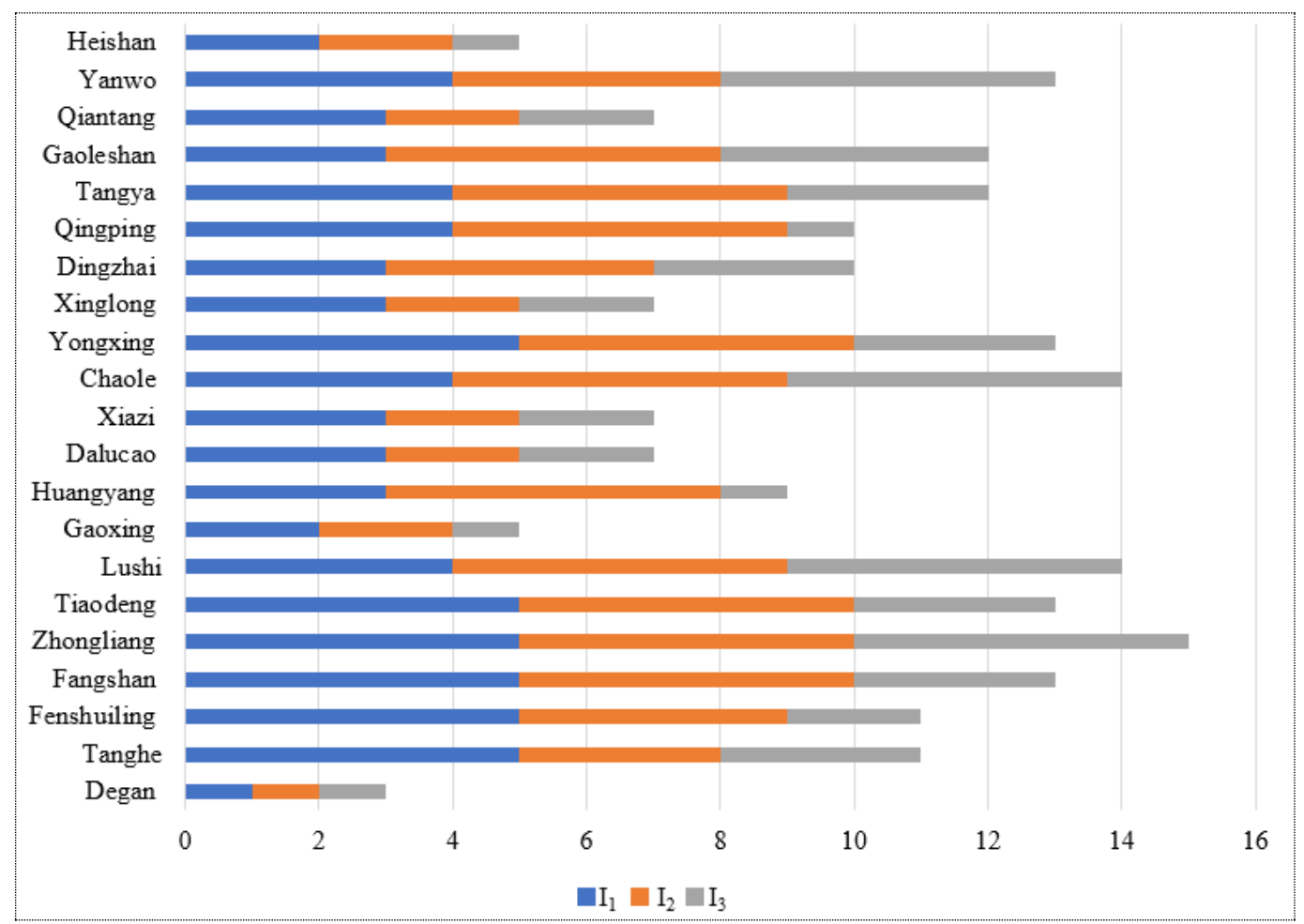

Figure 5 Significance of institutional barriers to sample towns 


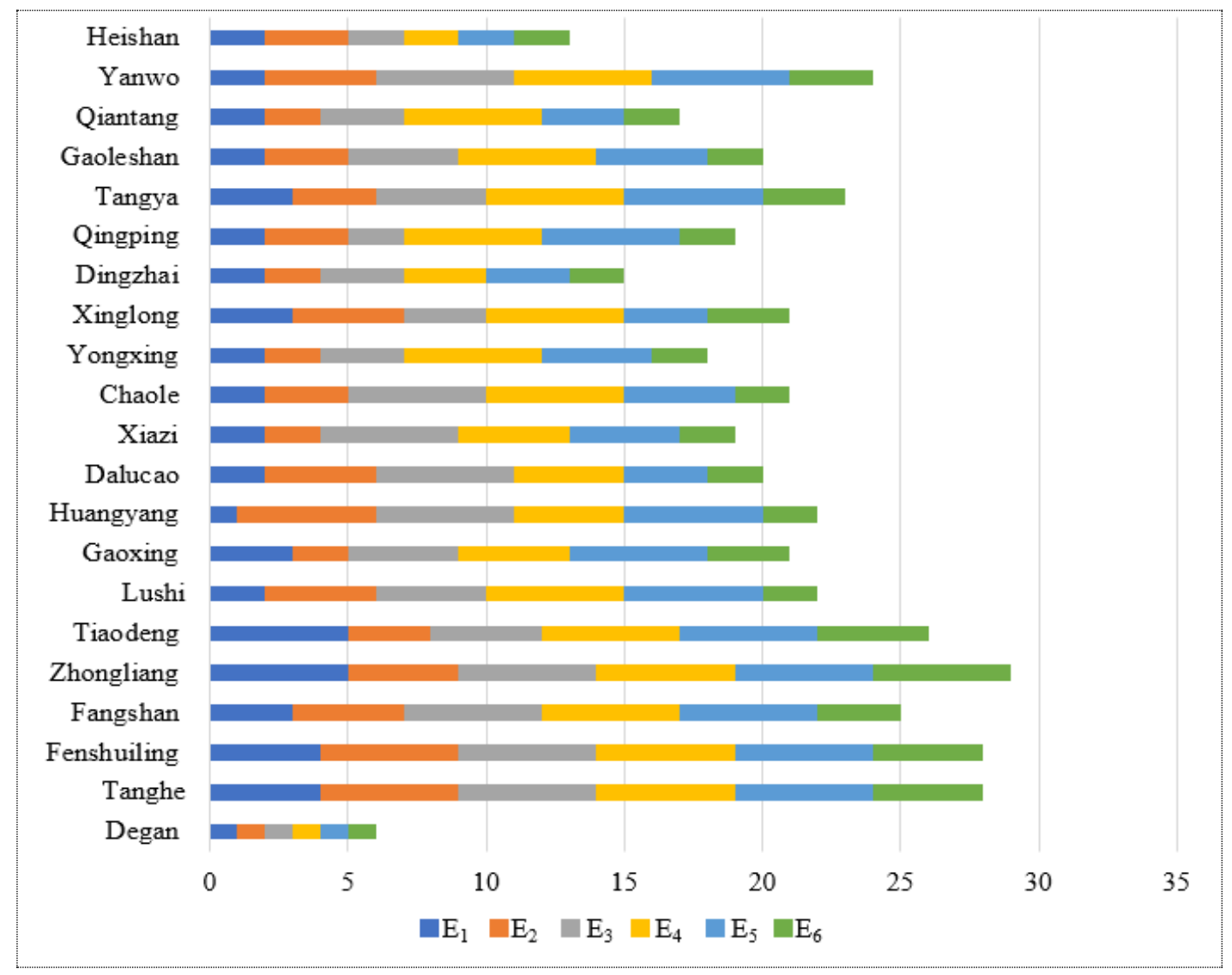

Figure 6 Significance of economic barriers to sample towns

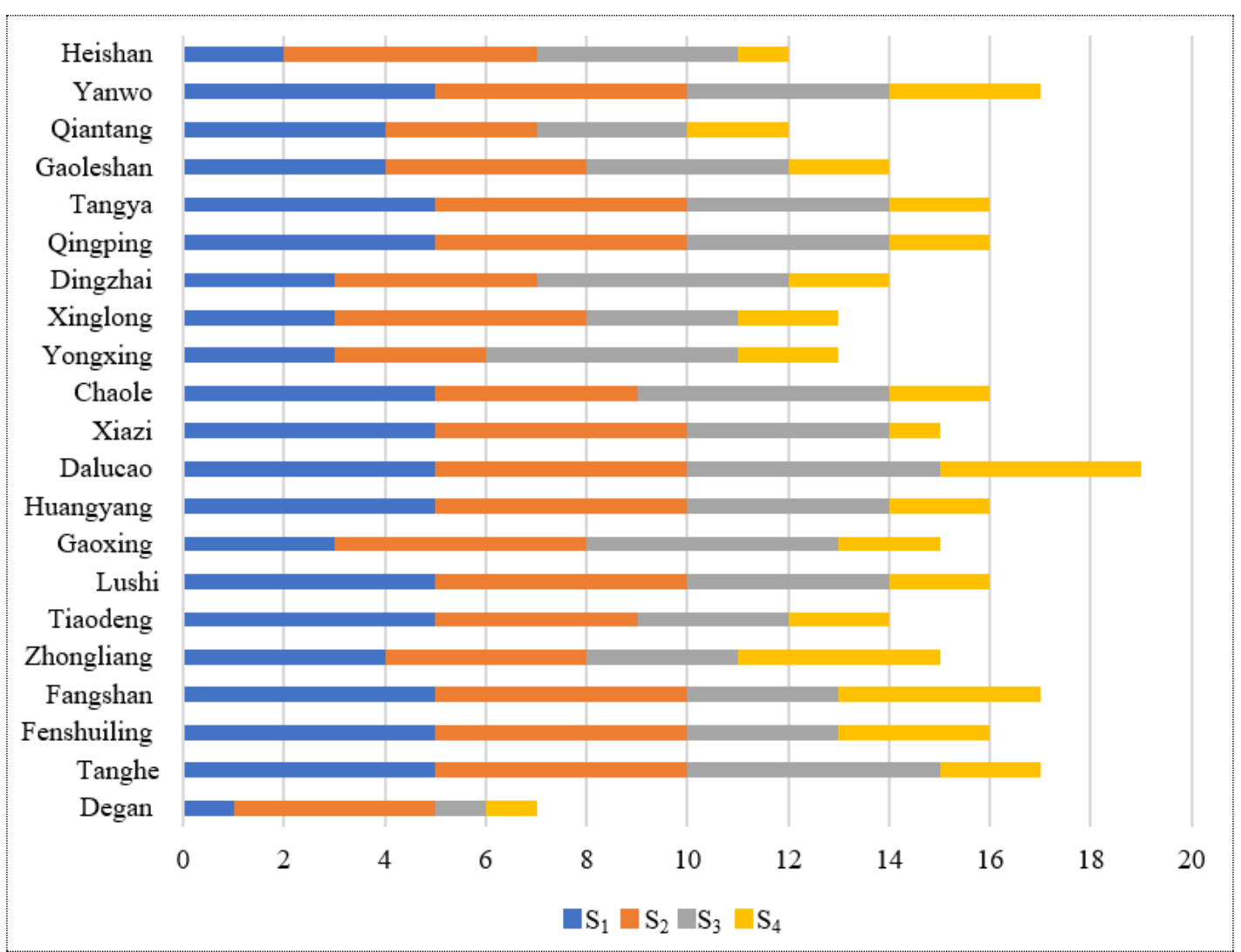

Figure 7 Significance of social barriers to sample towns 


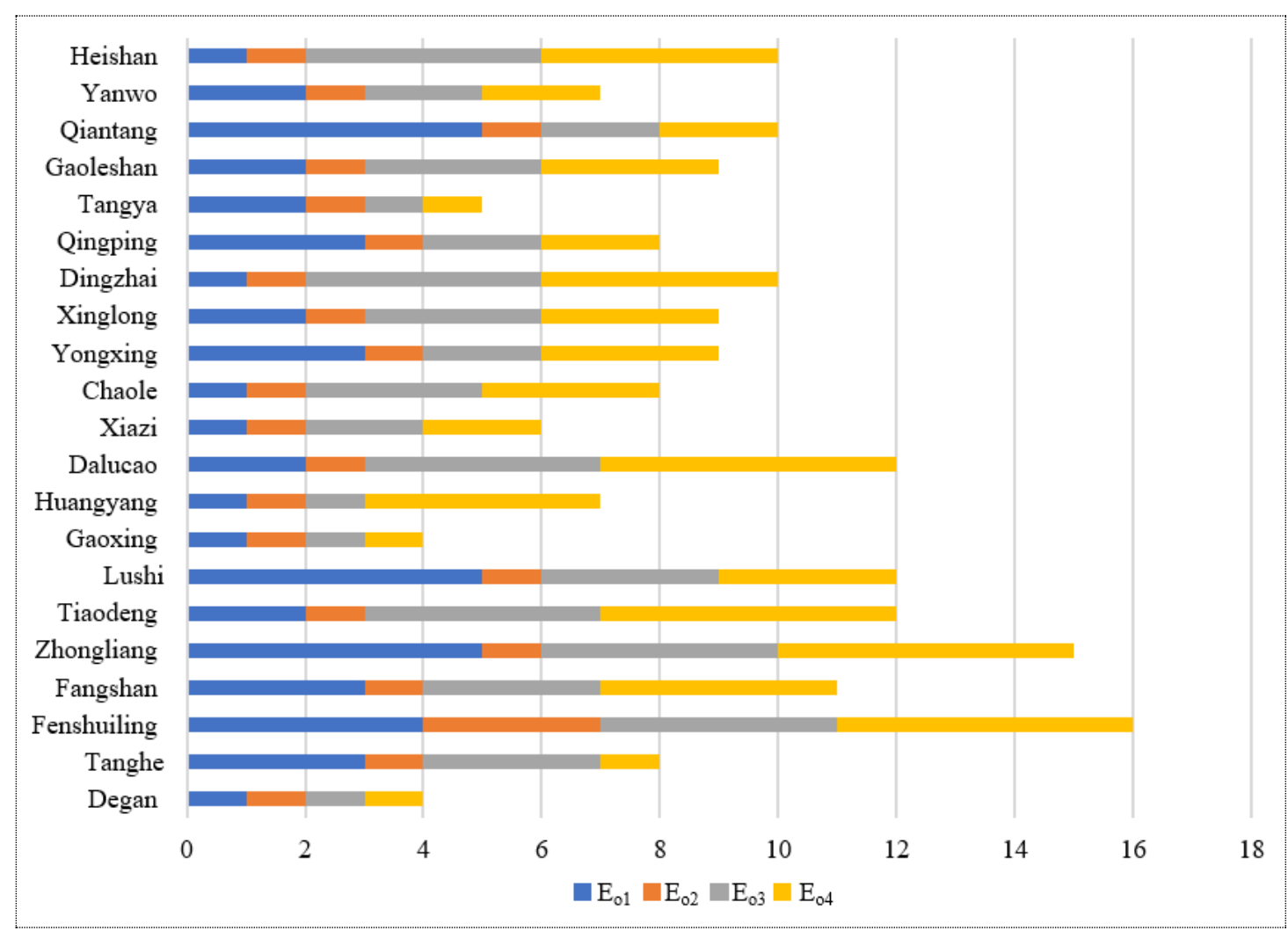

Figure 8 Significance of ecologic barriers to sample towns

\section{Discussions}

This section presents the discussions on the analysis results about the significance of the barriers across four dimensions.

\subsection{Institutional barrier}

As shown in Table 4 and Figure 4, the mean significance values of institutional barriers $\mathrm{I}_{1}$ (lack of independent financial power), $\mathrm{I}_{2}$ (restriction of jurisdiction power) and $\mathrm{I}_{3}$ (lack of construction land use quotas) are 3.62, 3.71, and 2.71 respectively. This indicates that the barrier $I_{1}$ and barrier $I_{2}$ are more significant in affecting the development of small towns in comparing to the barrier $\mathrm{I}_{3}$.

The hierarchy of the Chinese administration management system is designed as a five-tier system, including the top level central government, provincial government (municipality city, autonomous region), city-level government, county-level government and the bottom-layer township government. This system disadvantages small towns in the urbanization process in two ways: the allocation of resources is 
biased towards upper-level administrations, such as counties and cities; and the development at township level is often overlooked.

\section{Lack of independent financial power $\left(I_{1}\right)$}

The barrier $I_{1}$ (lack of independent financial power) is significant, as shown in Figure 4. Small towns have limited administration autonomy. The tax in small towns is collected by county-level governments, and the financial resources for the operation of towns are also allocated by county governments. It was reported in the interviews that the financial resources are severely insufficient to meet the demands for implementing development programs in small towns. For example, Zhongliang Town, located in Shapingba District of Chongqing Municipality City, submits all the township tax income to Shapingba District. According to the interviews discussions with the officials in this town, Shapingba District appropriates between RMB 10 to 11 million annually to Zhongliang Town. This income is considered only being able to cover the basic administration cost for running the town, with very little left for engaging other township development programs.

\section{Restriction of jurisdiction power $\left(I_{2}\right)$}

Township governments in China enjoy very limited jurisdiction power and have limited authority to plan their development programs. This situation is overwhelmingly echoed by interviewees. For example, according to the discussions with the officials in Yongxing and Lushi towns, they have almost no independent jurisdiction powers but have the responsibilities in protecting local security, and maintaining the operation within the township territory. An example is that they can only exhort the traffic regulation violators but have no jurisdiction to impose punishment. Without jurisdiction power, these small towns cannot make effective decisions on the program for development. For another example, according to the interview discussion in Tiaodeng town, located in Dadukou District of Chongqing Municipality City, the township jurisdiction power is limited to the execution of the tasks defined by its upper Dadukou district government. The township government only assumes the function of providing public service. Actually the impact of barrier 
$\mathrm{I}_{2}$ (restriction of jurisdiction power) appears most significant in a number of sample towns, including Yongxing, Gaoleshan, Lushi, Tiaodeng and Fangshan, as evidenced in Figure 5.

There are also cases where towns have limited right to utilize the local resources for implementing economic activities. It is considered that the distribution between jurisdiction power, responsibility, and benefit for township governments is unbalanced. According to the site visits and the discussions with the officials in Fangshan, there is a famous buddhist tourism resort within the township territory, named Fangshan Scenic Spot. The resort is under the governance of Fangshan Scenic Spot Management Council, which is administratively more senior than the township government of Fangshan. Under this circumstance, all the incomes generated in the spot are collected by Fangshan Scenic Spot Management Council instead of the Fangshan township government. However, the local government is accountable to the management responsibilities for local transportation, commercial activities and social security in the spot area. It appears from the discussions that the unbalance between the responsibilities assumed and the benefits received discourages the local government and restricts the development of Fangshan. In fact, it is implied during the discussion that the development of Fangshan town is much left behind in the whole Luzhou region.

\section{Lack of construction land use quotas $\left(I_{3}\right)$}

Another major institutional barrier to the development of small towns is lack of land use quotas. As land is the main resources for urbanization, the land use policy has essential influence on the development of urbanization for both cities and small towns. The Chinese central government adopts a restrictive quotas system of construction land use for protecting cultivation land, and all levels of governments need to follow the allocations and specifications of land use quotas. According to the quotas system, construction land use quotas are distributed to each province, which in turn are further allocated to lower level administrations. As the administration at each hierarchical level tends to position its own development in priority, township 
government, which is the bottom layer in the administration hierarchy, is consequently given little quotas of construction land. As a result, the development of small towns is heavily restricted with insufficient construction land. The limited land for construction in small towns presents a major barrier for attracting external investment and developing non-agriculture industries.

According to the interview discussions in Yanwo town, which is located in Hechuan district of Chongqing city, as the construction land use quotas allocated are insufficient and fragmented geographically, this town can neither utilize the construction land intensively nor achieve scale effects in developing economic activities. The interviewees suggest that the insufficient land use quota is the most severe barrier to the development of Yanwo. For another example, during the discussions in Zhongliang, the township chief also opined that the insufficient quotas of construction land use and restricted land use planning authority have limited the process of urbanization in this town and affected the township sustainable economic development. The significance of the barrier $\mathrm{I}_{3}$ (lack of construction use quotas) to the township development can be evidenced in Figure 5, where the effects of the barrier are particularly obvious in Yanwo, Lushi and Zhongliang.

The above discussions on institutional barriers demonstrate that in general small towns have not been given sufficient power to make decisions on the aspects of land use, finance and township planning. The concerns about the capability of township government in practicing decision-making on these aspects are understandable. It is suggested that more administrative autonomy should be delegated to those towns which have good social economic performance and better-quality officials. Previous studies have also demonstrated the importance of delegating proper authority to township government for sustainable development as township governments have better knowledge about the conditions of towns ( $\mathrm{Gu}$ et al., 2015; Deng et al., 2014). With proper institutional power, the township government, the grass-roots administration in the Chinese administration 
management hierarchy, can make more contributions to the development of management efficiency, social development and economic prosperity at township level.

\subsection{Economic barrier}

In view of economic barrier to the development of small towns in Table 4 and Figure 4 suggest that the barrier $\mathrm{E}_{4}$ (limited financing channels) and $\mathrm{E}_{5}$ (lack of financial support to infrastructure construction) are most severe, $\mathrm{E}_{2}$ (low level of agricultural industrialization) and $\mathrm{E}_{3}$ (mono-industry structure) are significant, while $E_{1}$ (underdeveloped township enterprises) and $E_{6}$ (difficulty of forming scale economy due to the spatially diffused distribution of township enterprises) are considered not significant.

Limited financing channels $\left(E_{4}\right)$ and lack of financial support to infrastructure construction (Es)

Most of the small towns in China have limited channels for obtaining financial resources (Liu and Zhang, 2016). Government investment is the main resources particularly for the small towns in Southwest China, but the investment is limited. During the interview discussion in Fenshuiling, the officials pointed out the difficulty of urbanization development as it only relies on the fiscal revenues. For instance, the construction of a main road in this town was sponsored by the upper level government and started in 2008, but the project still remained uncompleted at the time of this research survey due to the insufficiency of finance. In fact, it is common that the government investment is the only finance channel for small towns to develop infrastructure projects which are very often delayed or uncompleted. The interview discussions in other towns such as Zhongliang, Fenshuiling, Tanghe, Yanwo, Tiaodeng, Tangya, Huangyang suggested that the finance appropriation from upper government level is usually project-based, only those projects larger than certain scale will be considered. For example, the projects seeking for national-level fund must be at the scale of more than US\$14 million. However, the projects proposed at township level are usually just at the scale of less than US\$1.4 million. 
Therefore many projects proposed at township level can not be funded by upper level government. This leads to a dilemma that the projects in small towns will not be registered by upper level government and be financially supported as they are not large enough. This scale criterion for considering fund support is viewed overwhelmingly as a major barrier affecting township development in Southwest China.

The importance of having multi finance-channels for implementing infrastructure projects at town level can be further evidenced in the case of Wenxing Reservoir in Dalucao, located in Guizhou Province. The public-private-partnership (PPP) model is adapted for the construction of this project. By using both social capital and public finance, PPP model offers more financial channels to support this project and enables the project completed on time. In fact, the successful experience of Wenxing Reservoir project can be promoted to other towns for application in developing infrastructure projects.

\section{Mono-industry structure ( $\left.E_{3}\right)$ and low level of agricultural industrialization $\left(E_{2}\right)$}

According to the survey, the industry compositions of the 21 sample towns are listed in Table 5. The table tells that the economy of the surveyed towns is overwhelmingly dominated by traditional agriculture for producing crops. The agriculture in these small towns is at low-level industrialization with little value-added, and can not generate good economic outcomes. According to the interview discussion in Huangyang, the dominant industry in this town is the production of pepper and flue-cured tobacco at primary level without product processing and marketing promotion. As a result, although this town produces good primary materials of pepper and tobacco, it is a pity to see that the economic development of the town is still at very low level. The significant effects of barriers $\mathrm{E}_{2}$ (low level of agricultural industrialization) and $\mathrm{E}_{3}$ (mono-industry structure) for Huangyang are also evidenced in Figure 6. 
Table 5 The industry composition in the 21 case towns

\begin{tabular}{|c|c|}
\hline Surveyed towns & Industry composition \\
\hline Degan & $\begin{array}{l}\text { Primary industry (selenium-rich agriculture, aquaculture); Secondary industry } \\
\text { (equipment manufacturing, grain and oil processing); Tertiary industry (logistic } \\
\text { industry) }\end{array}$ \\
\hline Tanghe & Tertiary industry (tourism-historic town) \\
\hline Fenshuiling & Primary industry (crop production); Tertiary industry (agricultural sightseeing) \\
\hline Fangshan & Primary industry (crop production); Tertiary industry (tourism) \\
\hline Zhongliang & $\begin{array}{l}\text { Primary industry (ecological agriculture); Tertiary industry (sightseeing } \\
\text { tourism) }\end{array}$ \\
\hline Tiaodeng & $\begin{array}{l}\text { Primary industry (ecological agriculture); Secondary industry (mining); Tertiary } \\
\text { industry(tourism) }\end{array}$ \\
\hline Lushi & $\begin{array}{l}\text { Primary industry (crop production); Secondary industry (agricultural products } \\
\text { processing); Tertiary industry (sightseeing tourism) }\end{array}$ \\
\hline Gaoxing & Primary industry (crop production); Tertiary industry (sightseeing tourism) \\
\hline Huangyang & Primary industry (crop production); Tertiary industry (tourism) \\
\hline Dalucao & Primary industry (crop production); Tertiary industry (tourism) \\
\hline Xiazi & Primary industry (crop production); Tertiary industry (trade and commerce) \\
\hline Chaole & $\begin{array}{l}\text { Primary industry (crop production, poultry breeding); Secondary industry } \\
\text { (stone-processing industry) }\end{array}$ \\
\hline Yongxing & Primary industry (crop production); Tertiary industry (tourism) \\
\hline Xinglong & $\begin{array}{l}\text { Primary industry (crop production); Secondary industry (tea-making, food } \\
\text { processing); Tertiary industry (tourism) }\end{array}$ \\
\hline Dingzhai & Primary industry (crop production, poultry breeding) \\
\hline Qingping & $\begin{array}{l}\text { Primary industry (crop production); Secondary industry (building material } \\
\text { industry) }\end{array}$ \\
\hline Tangya & Primary industry (crop production, poultry breeding) \\
\hline Gaoleshan & $\begin{array}{l}\text { Primary industry (crop production); Secondary industry (tea-making, } \\
\text { stone-processing industry) }\end{array}$ \\
\hline Qiantang & $\begin{array}{l}\text { Primary industry (crop production); Secondary industry (automobile } \\
\text { manufacturing, food processing) }\end{array}$ \\
\hline Yanwo & Primary industry (crop production) \\
\hline Heishan & $\begin{array}{l}\text { Secondary industry (agricultural products processing); Tertiary industry } \\
\text { (tourism, real estate business for tourism) }\end{array}$ \\
\hline
\end{tabular}

It appears that most of the surveyed towns have started the tertiary industry of tourism. Nevertheless, the mono industry model of tourism may have limitation in promoting local economic development in small towns. For example, in light of the interview discussion in Tanghe, a historic town, the officials opined that the tourism development in the town lacks commercial supports and professional skills to operate and manage the historic characteristics. It was found that this town has no 
other industry activities except tourism, whilst the income generate from tourism is limited. Therefore, the tourism designed for historic attractions in Tanghe does not contribute much to the local economic development. As a result, without other industry activities, the economic development of Tanghe is still at low level. The significance of the barrier $\mathrm{E}_{3}$ (mono-industry structure) in affecting economic development in Tanghe is also evidenced in Figure 6.

\subsection{Social barrier}

The effects of social barriers are illustrated in Table 4 and Figure 4 . It can be seen that the barrier $S_{1}$ (loss of labor-force population) and $S_{2}$ (lack of talents for township development) are most significant social barriers in hindering small towns from development, followed by barrier $S_{3}$ (low level of management capability), whilst barrier $\mathrm{S}_{4}$ (difficulty in forming scale effect due to small population) is not considered significant.

Loss of labor-force population $\left(S_{1}\right)$ and lack of talents for township development $\left(S_{2}\right)$

Many small towns in Southwest China have been losing labor forces and talents significantly during the urbanization process. It is commonly appreciated that urbanization process in China has led to population flow from rural area to either cities or small towns (Wang and Fei, 2014), which can be described graphically in Figure 9. However, the less developed economy and social services of small towns in Southwest China present feebleness in absorbing rural population. In other words, the attractiveness of the small towns in Southwest region for rural population is weaker than that of cities. Therefore, rural population tend to migrate into cities for better jobs and education opportunities, resulting in the loss of labor forces and talents for the development of small towns in this region. This phenomenon can be explained by the push-pull theory. According to the theory, the migration of population is driven by the synergy of the "push force" from population outflow area and the "pull force" of population inflow area (Gu et al., 1999; Liang and Ren, 2010; Zhang, 2014). Obviously, cities have stronger pull force for population flow than that of small towns particularly in Southwest China. 


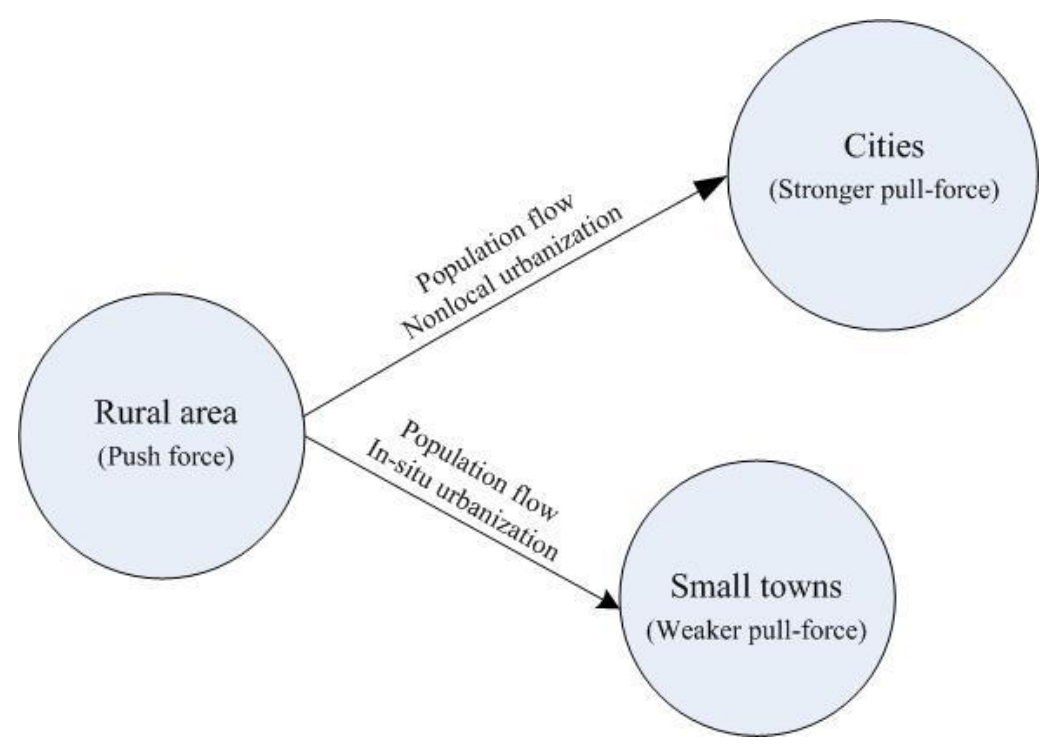

Figure 9. Population flow in Chinese urbanization process

During the field survey in Tanghe, for example, it was reported that $60 \%$ of its labor forces has flowed to cities, with only aged people and young children left in the town. Though the township government has an ambitious plan of developing a tourism industry with historic attractions, the lack of labor-force and talents presents major barrier to the implementation of the plan. For another case in Dalucao, according to the interview discussion, over $50 \%$ of working-age people have left the town for cities. The loss of labor forces hinders the progress of infrastructure construction in this town. As further mentioned early, Dalucao has planned tourism as its main industry, and it can be expected that this plan can not be implemented effectively because of the shortage of labors and talents. The effects of labor and talent loss on the development of small towns is overwhelmingly echoed in case towns, which can be seen in Figure 7.

\section{Low level of management capability $\left(S_{3}\right)$}

Low level of management capability is also a significant social barrier in affecting the development of small towns, echoed in almost all the interview discussions in the surveys. It is common that the township administrators are insufficient in number and many of them have limited ability in assuming their positions. According to the discussions in Tanghe, Dalucao, Lushi, Qingping and Tangya, many officials in these towns commit various types of tasks in different 
sections at the same time, such as environmental protection, tourism development, infrastructure construction and maintenance. Virtually, according to the surveys, there is no individual official in charge of tasks in a single sector. In other words, an individual official may have to be responsible for tasks in several sections at the same time, resulting in that individual officials can not perform their tasks effectively as obviously they can not be professional in many sections. This has resulted in the consequence of low-level management capability among almost all township officials.

\subsection{Ecologic barrier}

From ecologic perspective, the barrier $\mathrm{E}_{04}$ (conflict between industrial business and environmental protection) is the major barrier in affecting the development of small towns, as shown both in Table 4 and Figure 4 , followed by the barrier $E_{o 1}$ (topographic variety and complexity) and $\mathrm{E}_{03}$ (limited ecological carrying capacity). Barrier $\mathrm{E}_{\mathrm{o} 2}$ (frequent natural disasters) is considered insignificant.

\section{Conflict between industrial business and environmental protection $\left(E_{04}\right)$}

There is a conflict between the development of industries and the protection of environmental resources in small towns in the urbanization process in China, as appreciated in the interview discussions. This is particularly the case to those small towns where there are rich resources such as mineral materials for industrial business. The implementation of environmental protection policies has led to the closure of many industrial businesses developed in the past in these small towns. These businesses are requested to transfer to other eco-friendly economic activities. However, the difficulty of the business transformation is widely appreciated. From the interview discussion in Zhongliang, where the dominant industry used to be mineral exploitation, it was in leading position in economic performance among the towns in Chongqing City. However, after the year 2010, when Chongqing government introduced the environment protection policy requesting the closure of all the quarry businesses, Zhongliang closed its mineral exploitation activities. This town repositioned its development orientation as "restraining secondary industry and 
promoting the integration of primary and tertiary industry". The new dominant industry defined in Zhongliang is ecologic agriculture and sightseeing tourism. Nevertheless, as opined by the interviewees, the industry transformation in Zhongliang is not effective as both tourism and ecologic agriculture are well developed. Consequently, this town has suffered severe drawback in economic performance.

The effect of the barrier $E_{04}$ is also evidenced in other case towns such as Fenshuiling, Zhongliang, Tiaodeng and Dalucao, as shown in Figure 8. For the example of Tiaodeng, this town has rich mineral resources such as shale and dolomite, and the development of the town used to rely on the exploitation of the mineral resources for cement production. The cement industry used to provide employment opportunities for local people, which contributed not only to the economic development but also to the promotion of the township urbanization process. However, the enforcement of environment protection policy introduced in 2011 has led to the closure of most cement manufactories in this town, consequently, its economic performance has been dropping dramatically in recent years. Although the township government has been implementing sightseeing tourism as the countermeasure, the contribution of the new industry to the development of this town is very limited because the town has little characteristic resources for tourism.

$\underline{\text { Topographic variety and complexity }\left(E_{01}\right) \text {, and limited ecological carrying capacity }}$ $\underline{\left(E_{03}\right)}$

As shown in Table 4 and Figure 4 , the ecologic barriers $E_{01}$ (topographic variety and complexity) and $\mathrm{E}_{03}$ (limited ecological carrying capacity) are also significant in hindering the development of small towns in Southwest China. The Southwest region is a typical mountainous area, where more than $70 \%$ of the territory is mountainous (Cao et al., 2011). The topography in this region is very complex, which limits the township development in cluster and scale for agriculture, infrastructure and industry in these towns. On the other hand, these small towns have limited ecological resources such as land and water for urbanization 
development. In other words, these towns have limited ecological carrying capacity for their development. According to the field survey in Lushi, a typical mountainous town, the development of the town is severely hindered because its land is barren and in steep gradient, which is neither drought resistant nor flood preventative. The discussions suggest that this town has very low-level grain production and severe land desolation. The effect of the barrier $\mathrm{E}_{\mathrm{o} 1}$ (topographic variety and complexity) in Lushi can also be found in Figure 8. In fact, it is difficult for mountainous towns with poor topographic conditions to find alternative development approaches.

\section{Conclusions}

China has been experiencing a rapid urbanization process during the past several decades, and the urbanization has brought many benefits throughout the country. However, it appears that small towns particularly in Southwest China are at a disadvantage to large extent in sharing these benefits. These small towns are still largely left behind in comparing to cities or those small towns in developed regions. This study presents holistically the barriers that hinder small towns in Southwest China from sharing the benefits brought by urbanization process. These barriers are in four dimensions, namely, institutional, economic, social and ecologic dimensions. The most significant institutional barriers include lack of independent financial power, and restriction of jurisdiction power. In economic aspect, the most significant barriers are low level of agricultural industrialization, mono-industry structure, limited financing channels, and lack of financial support to infrastructure construction. In social dimension, the most significant barriers are loss of labor-force population, lack of talents for township development, and low level of management capability. And the conflict between industrial business and environmental protection is the most significant ecological barrier. These barriers

hinder small towns in Southwest China from sharing benefits induced by urbanization process as they can not utilize effectively their self-borne resources and attract external investment. 
The findings from this study provide important reference to support the solution-searching for a balanced development between urban and rural areas in the urbanization process in China. The understanding on these findings contributes to removing the bottlenecks for the development of small towns and achieving the mission of new-type urbanization in China. On the other hand, the study contributes to the development of the literature in the field of urban-rural studies. The holistic view in examining barrier significance can be applied to study the barriers to the development at township levels in other regions and countries.

It is appreciated that the 21 case towns referred in this study may have limitations in representing small towns in China as there are large number of small towns in the country. Given the variety of small towns in China, it is recommended for further study to examine the barriers in relation to different types of small towns, and search for effective approaches to help small towns share more benefits brought by the urbanization process in China.

\section{Acknowledgement}

This study was supported by the National Social Science Foundation of China (Grant No. 15BJY038). Special thanks are also to those officials in the 21 case towns in Southwest China for their supports to research surveys and data collections.

\section{Reference}

Aguilar-Escobar, V. G., Vega, P. G., \& Zamora, M. D. M. G., 2016. Applying the theory of constraints to the logistics service of medical records of a hospital. European Research on Management \& Business Economics, 22(3), 139-146.

Balderstone, S. J., \& Mabin, V. J., 1998. A review of goldratt's theory of constraints (toc)-lessons from the international literature. In Annual Conference of the Operational Research Society of New Zealand.

Balderstone, S. J., \& Mabin, V. J., 2013. The performance of the theory of constraints methodology: analysis and discussion of successful toc applications. International Journal of Operations \& Production Management, 23(6), 568-595. 
Bao, H., \& Peng, Y., 2016. Effect of land expropriation on land-lost farmers' entrepreneurial action: A case study of Zhejiang Province. Habitat International, 53, 342-349.

Cao, W., Tao, H., Kong, B., \& Liu, B., 2011. Topographic automatic recognition based on optimal topography feature space-taking southwest China as an example. Geomatics and Information Science of Wuhan University, 36(11), 1376-1380.

Chen, M., Liu, W., \& Lu, D., 2015. Challenges and the way forward in china's new-type urbanization. Land Use Policy, 55, 334-339.

Chen, M. Q., Liu, T., J., 2004. Analysis on system obstructions to small town sustainable development and countermeasures in china. China Population Resources \& Environment, 14(1), 58-61.

Cohen, I., Mandelbaum, A., Shtub, A., 2004. Multi-project scheduling and control: a process-based comparative study of the critical chain methodology and some alternatives. Project Management Journal 35 (2), 39-50.

Costas, J., Ponte, B., de la Fuente, D., Pino, R., \& Puche, J., 2015. Applying Goldratt's Theory of Constraints to reduce the Bullwhip Effect through agent-based modeling. Expert systems with Applications, 42(4), 2049-2060.

Cui, S., \& Zhao, Q., 2013. The inspiring and thinking for in-situ urbanization of south jiangsu. Urban Development Studies, 20(10), 47-51.

Deng, J., Z., Yu, T., Feng, J., 2014. A research on regional spatial effects of authority enlargement at township level based on the perspective of institutional change- A case study of Dainan Town in Jiangsu. Modern Urban Research (10), $39-45$.

Fan, W., 2003. The reasons for the lagged development of small town in west china and strategies to accelerate the future development. Research on Development (2), 47-49.

Fang, C., Zhao, W., \& Wei, X., 2014. Ecological restriction and urban planning in southwestern mountainous region. Planners, 2014(11), 93-100.

Goldratt, R., \& Weiss, N., 2005. Significant enhancement of academic achievement through application of the Theory of Constraints (TOC). Human Systems Management, 24(1), 13-19.

Golmohammadi, D., 2015. A study of scheduling under the theory of constraints. International Journal of Production Economics, 165, 38-50.

Government Work Report, 2015. State council, The People's Republic of China. http://www.gov.cn/guowuyuan/2015-03/16/content_2835101.htm

Gu, C., Cai, J., Zhang, W., Ma, Q., Chan, R. C. K., Li, W., \& Shen, D., 1999. A study on the patterns of migration in Chinese large and medium cities. Acta Geographica Sinica, 54(3), 204-212. 
Gu, C., Li, Y., \& Han, S. S., 2015. Development and transition of small towns in rural china. Habitat International, 50, 110-119.

Guo, X., Xia, X., Zhang, X., \& Feng, C., 2014. Comprehensive evaluation analysis of small towns development level in china's different regions. Areal Research \& Development, 33(5), 50-54.

Hubacek, K., Guan, D., Barrett, J., \& Wiedmann, T., 2009. Environmental implications of urbanization and lifestyle change in China: Ecological and water footprints. Journal of Cleaner Production, 17(14), 1241-1248.

International Monetary Fund. http://www.imf.org/external/index.htm

Langmack, K. A., Newton, L. A., Jordan, S., \& Smith, R., 2015. Cone-beam ct dose reduction in prostate radiotherapy using likert scale methods. British Journal of Radiology, 20150460.

Liang, H., \& Ren, Y., 2010. Being migrant or being left behind: Determinants of migration of children of the peasant workers. Population Research, 34(2), 57-65.

Liu, M., \& Zhang, Z. C., 2016. Restriction Factors and Countermeasures of New Urbanization in Henan Province. Economic Geography, 2016(3), 78-82.

Liu, Y. Y., Fan, L. H., \& Xue, D. S., 2006. The land use and its systematic obstacles in small towns of export-oriented regions_a case study of liaobu town in dongguan city. Tropical Geography, 26(1), 51-55.

Lu, D., Huang, J., 2012. From growth to transformation: the development characteristics, practical problem and strategy about small towns in pearl river delta. Economic Geography, 2012(9), 21-25.

Luo, X., Zhang, J., Jiang, X., 2000. The thinking for small towns development under the transition of southern Jiangsu' model. Urban Planning Forum, 2000 (5), 26-27.

Luo, X., Zhang, J., \& Yin, J., 2011. Institution innovation: new development of southern Jiangsu's urbanization. City Planning Review, 2011(5), 51-55.

Lipton, M., 1993. Urban bias: of consequences, classes and causality. The Journal of Development Studies, 29(4).

National Bureau of Statistics of China. http://data.stats.gov.cn/index.htm

National New-type Urbanization Plan (2014-2020), 2014. China State Council, http://www.gov.cn/zhengce/2014-03/16/content_2640075.htm

Peng, Y., Shen, Q., Shen, L., Lu, C., \& Yuan, Z., 2014. A generic decision model for developing concentrated rural settlement in post-disaster reconstruction: a China study. Natural hazards, 71(1), 611-637.

Peng, Y., 2015. A comparison of two approaches to develop concentrated rural settlements after the 5.12 Sichuan Earthquake in China. Habitat International, 49, 230-242. 
Peng, Y., Lai, Y., Li, X., \& Zhang, X., 2015. An alternative model for measuring the sustainability of urban regeneration: the way forward. Journal of Cleaner Production, 109, 76-83.

Puche, J., Ponte, B., Costas, J., Pino, R., \& De la Fuente, D. (2016). Systemic approach to supply chain management through the viable system model and the theory of constraints. Production Planning \& Control, 27(5), 421-430.

Qi, X. H., Zhu, Y., \& Zhou, Y. P., 2012. A "double-pull" model of rural labor migration and its in situ urbanization effect: cases studies of three coastal areas in southeast china. Scientia Geographica Sinica, 32(1), 25-30.

Rasmussen, J. L., 1989. Analysis of likert-scale data: a reinterpretation of gregoire and driver. Psychological Bulletin, 105(1), 167-170.

Rogers, M. P., Orav, J., \& Black, P. M., 2001. The use of a simple likert scale to measure quality of life in brain tumor patients. Journal of Neuro-Oncology, 55(2), 121-131.

Shen, J., 2006. Understanding dual-track urbanization in post-reform china: conceptual framework and empirical analysis. Population Space \& Place, 12(6), 497-516.

Shen, L., Peng, Y., Zhang, X., \& Wu, Y., 2012. An alternative model for evaluating sustainable urbanization. Cities, 29(1), 32-39.

Shen, L., Shuai, C., Jiao, L., Tan, Y., \& Song, X., 2016. A global perspective on the sustainable performance of urbanization. Sustainability, 8(8), 783.

Shen, L., Shuai, C., Jiao, L., Tan, Y., \& Song, X., 2017. Dynamic sustainability performance during urbanization process between BRICS countries. Habitat International, 60, 19-33.

Shi, Y. S., 2013. New-type urbanization and small town development in china. Economic Geography, 33(7), 47-52.

Shi, Y. S., 2015. The Balanced Urbanization Mode of Germany and the System Bottlenecks of Development of Chinese Small Towns. Economic Geography, 35(11), 54-60.

Shuai, C., Chen, X., Shen, L., Jiao, L., Wu, Y., \& Tan, Y. (2017). The turning points of carbon Kuznets curve: evidences from panel and time-series data of 164 countries. Journal of Cleaner Production, 162, 1031-1047.

Shuai, C., Shen, L., Jiao, L., Wu, Y., \& Tan, Y. (2017). Identifying key impact factors on carbon emission: Evidences from panel and time-series data of 125 countries from 1990 to 2011. Applied Energy, 187, 310-325.

Song, J., 2004. Industrial optimization and institutional innovation of the towns in pearl river delta. City Planning Review, 28(9), 31-35. 
Stake, R. E., 1983. The Case Study Method in Social Inquiry. Evaluation Models. Springer Netherlands, 7(2), 5-8.

Tan, Y., Shuai, C., Jiao, L., \& Shen, L., 2017. An adaptive neuro-fuzzy inference system (ANFIS) approach for measuring country sustainability performance. Environmental Impact Assessment Review, 65, 29-40.

Tian, M., \& Chang, C., 2003. Small towns' development and institutional innovation in china. City Planning Review, 27(7), 22-26.

Wang, X. R., Hui, C. M., Choguill, C., \& Jia, S. H., 2015. The new urbanization policy in china: which way forward? Habitat International, 47, 279-284.

Wang, Z., \& Fei, J. 2014. Space Choice of Population Migration: Local Urbanization or Remote Urbanization. Finance and Trade Research, 25(6), 61-67.

Wang, Z., Z., \& Sun, H., L., 2016. Countermeasures for the development of new-type small towns in west china. Economic Review, 2006 (1), 74-77.

Wang, J. R., 2011. On the current difficulties and solutions of the small towns' economic development in china. Qilu Journal, 2011(3), 85-88.

Watson, K. J., Blackstone, J. H., \& Gardiner, S. C., 2007. The evolution of a management philosophy: The theory of constraints. Journal of operations Management, 25(2), 387-402.

Weber, R. P., 1990. Basic content analysis. Sage Publications, 23(3), 310.

World Bank Open Data. http://data.worldbank.org/

Wu, M., \& Liu, S., 2012. Reason analysis of the lag development of small and medium-sized towns in urbanization process. Urban Problems, 2012(9), 40-44.

Yang, X. J., 2013. China's rapid urbanization. Science, 342(6156), 310-310.

Yu, A. T. W., Wu, Y., Shen, J., Zhang, X., Shen, L., \& Shan, L. (2015). The key causes of urban-rural conflict in china. Habitat International, 49, 65-73.

Yu, L., \& Peng, J., 2014. Existing problems and countermeasures of development and management of small towns in china. Urban Planning International, 2014(1), 62-66.

Yu, L., 2013. Urban-rural development policies in uk and some lessons for chinese small town development. Urban Development Studies, 20(11), 27-31.

Zhang, K., 2014. Driving factors and the suggestion of rural population mobility in China: Based on the "push and pull theory" in amended todar migration modal. Statistics \& Information Forum, 29(7), 22-28.

Zhang, L., 2012. Small towns but grand strategies_—a study on the development of small towns in provinces with net out-migration. Urban Planning Forum, 2012(1), 23-32. 
Zhang, W., H., 2011. Study on Problems and Solutions about Construction of Small Towns in Guizhou Province. Journal of Anhui Agricultural Sciences, 2011, 39(3), 1812-1814,1818.

Zhen, W., J., \& Zhao, Q., 2016. Problems for the development of small towns in underdevelopment area. Economic Review, 2016 (11), 104-107. 